\title{
The Teachers' Knowledge of the Spirit of Nationality and Its Implementation Strategy: A Study to Improve the Spirit of Nationality
}

Sukowati

Graduate School, Universitas Negeri Yogyakarta, Yogyakarta, Indonesia, sukowati.2018@student.uny.ac.id

\section{E. Kus Eddy Sartono}

Graduate School, Universitas Negeri Yogyakarta, Yogyakarta, Indonesia, kus_edisartono@uny.ac.id

Mohammad Adam Jerusalem

Graduate School, Universitas Negeri Yogyakarta, Yogyakarta, Indonesia, adam_jerusalem@uny.ac.id

Puji Rahmawati

Primary School Teacher Education, Universitas Muhammadiyah Magelang, Magelang, Indonesia, pujirahmawatik@gmail.com

The spirit of nationality is one of the characters of students that must be developed through teaching and learning activities. The teachers' knowledge of the spirit of nationality and the implementation strategy is one of the keys to success in education. The objective of this study is to describe the extent of teachers' knowledge about the spirit of nationality. This study is a type of qualitative research with a phenomenological approach. The participants in this study included 25 public and private elementary school teachers from 8 provinces in Indonesia. The data was collected through focus group discussions (FGD) and interviews. The data analysis was carried out using Bogdan \& Biklen's model. The FGD and interview analysis was intended to obtain information on 6 sub-themes; the teachers' knowledge about the character of the spirit of nationality, strategies to improve the character of the spirit of nationality, obstacles in applying the character of the spirit of nationality, the urgency of the character of the spirit of nationality compared to other characters, measurements and assessments used to evaluate the character of the spirit of nationality of students. The results of this study show that the teachers' knowledge of the spirit of nationality, strategies to improve the character of the spirit of nationality of students, and strategies to enhance the character of the spirit of nationality of students are still low. On the other hand, there is the fact that the teachers already understand the importance of the character of the spirit of nationality and its relation to learning by using various innovative models. In addition, the teachers can identify obstacles in improving and enhancing the character of the spirit of nationality of students. That way, the teacher will know what to do. So that learning will be innovative.

Keywords: the character of the spirit of nationality, teachers' knowledge, teaching, learning, nationality

\section{INTRODUCTION}

One of the indicators of the success of the national vision is the implementation of education. Educational success is one of the keys to a better future. In practice, educational success is inseparable from the stakeholders, which is the government. The government as a policymaker has the main role

Citation: Sukowati., Sartono, E. K. E., Jerusalem, M. A., \& Rahmawati, P. (2021). The Teachers' Knowledge of the Spirit of Nationality and Its Implementation Strategy: A Study to Improve the Spirit of Nationality. Anatolian Journal of Education, 6(1), 117-130. https://doi.org/10.29333/aje.2021.6110a 
and major responsibility for the educational success by equalizing education, for example providing free education (by providing free funding education). In addition, the role of the teachers is no less important than the government because the teachers carry out all education policies and regulations set by the government (Qodriyah, Sri Hariyati \& Wangid, 2015).

The quality of education is also determined by the quality of its implementation which requires supervision from education experts, practitioners, and stakeholders. Those three partners must work together to achieve educational success through evaluation increase, curriculum improvement, and new policies as well as to develop teachers' professionalism (Rusman, 2010). The results of previous studies from several countries revealed that teachers make a major contribution to improving the quality of education (Hu, Fan, Yang, \& Neitzel, 2017). Therefore, the quality of teachers to implement education policies will influence the quality of education. Besides, the curriculum also plays a role to develop learning (Zaslow, Tout, Halle, Vick Whittaker, \& Lavelle, 2014), so the learning process that is designed must be in accordance with the applicable curriculum.

The curriculum used in Indonesia is the 2013 curriculum (K13). The curriculum used in schools must be able to introduce and practice $21^{\text {st }}$ century skills to students. There are 3 main skills in the $21^{\text {st }}$ century, consisting of 1) learning and innovation skills, 2) life and career skills, 3) information, media, and technology skills (Scott, 2017). The learning and innovation skills consist of critical thinking and problem-solving skills, collaboration skills, creativity skills, and communication skills (4C). The life and career skills consist of flexibility and ability to adapt to the environment, initiative and selfcontrol, cross-cultural sociability, productivity and accountability, leadership, and responsibility. Furthermore, information, media, and technology skills consist of information acquisition and media literacy (Kaufman, 2018). In addition, Bialik, Bogan, Fadel., \& Horvathova (2015) stated four main problems in the framework of the implementation of $21^{\text {st }}$ century education, including knowledge, skills, character, and metacognition.

Regarding character, one of the characters that students must possess is the character of the spirit of nationality. Improving and enhancing the character of the spirit of nationality is important for elementary school students because it becomes a stepping stone for students to have a sense of nationality as a form of the sense of responsibility from a citizen to their nation and country (Priyambodo, 2017). The character of the spirit of nationality is used to describe two important phenomena, which are the attitude of members of a nation to care about the identity of their country and the actions taken by citizens to defend their destiny (Heimonen \& Hebert, 2012; Mayall, \& Preece, 2011; Reid, 2010; Stanford Encyclopedia of Philosophy, 2008). In the school environment, the character of the spirit of nationality within students is built through character education. This character education is instilled through exemplary attitude and integration in the content of subject matter by the teachers, so that the teachers play an important role in character building (Ülger, Yiğittir, \& Ercan, 2014). Other than teachers, parents and the community are also involved in character education (MeiJu, Chen-Hsin, \& Pin-Chen, 2014). Quality collaboration between teachers, parents, and communities will build character naturally.

The spirit of nationality can also reduce the negative impact of ethnic heterogeneity from the remains of colonies (Ahlerup \& Hansson, 2011). The spirit of nationality arises in response to the political, social, and cultural conditions of colonial society, so that its manifestations have certain aspects (Kartodirjo, 1993). During the colonial period, nationalism functioned as an ideology of repelling colonialists (Reid, 2010), so that the spirit of nationality is a bond between two things in historical events.

In its implementation at school, the spirit of nationality is integrated into the content of the subject matter, so it needs to be developed, made explicit, and connected to everyday life (Daryanto \& Darmiatun, 2013). Bandura (1989) explained the behavior of individuals that is influenced by the 
environment through reinforcement and observational learning, including perspectives and ways of thinking about information, as well as how behavior can influence the environment, creating reinforcement, and opportunities for the observation that can be noticed by others. Besides, Bandura (1989) also said that the learning process is mostly obtained through imitation of behavior, although it does not receive the slightest reinforcement. An individual can imitate some of the behavior of others through observation results. Imitation of behavior that is carried out continuously will gradually become a habit and eventually become a character in children (Mustadi, 2011).

The results of the development of the character of the spirit of nationality can be achieved by the active role of the teachers in planning, implementing, and evaluating learning that is oriented to the instillation of character. Learning that is oriented to the spirit of nationality requires knowledge of ways, strategies, and methods to train students to have the character of the spirit of nationality (Risabethe \& Astuti, 2017). Ways that can be done to instill the spirit of nationality for elementary school students is to carry out habituation for students to attend the flag ceremony regularly, attend national holiday ceremonies, commemorate heroes' day, conduct historical visits, and join national holiday celebrations. (Anis, \& Tijan, 2013; Kurniawan, 2013). In addition, the character of the spirit of nationality can be implemented through creative and innovative learning, for example by utilizing interactive multimedia, picture books, augmented reality, flip map story books, etc. (Risabethe \& Astuti, 2017). Several studies showed that teachers still experienced obstacles in instilling the character of the spirit of nationality and had not yet found a suitable way to instill the character of the spirit of nationality. In addition, teachers also still find it difficult to make evaluations that show success in instilling the character of the spirit of nationality.

Based on the explanation, studies on the teachers' knowledge about the character of the spirit of nationality and its implementation strategy are still needed. This study is expected to provide a broad overview of the teachers' knowledge of the character of the spirit of nationality and its implementation strategy. The results of this study will assist in planning a program that can improve teachers' knowledge on the character of the spirit of nationality and its integration strategy. Therefore, the researchers intend to describe the teachers' knowledge of the character of the spirit of nationality and teachers' knowledge of the implementation strategy of the spirit of nationality in the class.

In this study, the relationship between the researchers and participants is to collect data through focus group discussions (FGD) and interviews about the knowledge of elementary school teachers on the spirit of nationality from eight provinces in Indonesia. The next step is to analyze data to find out more about teachers' knowledge. In the study conducted, the researchers did not give any action to the participants. The data obtained is pure data from the teachers' knowledge of the character of the spirit of nationality and its implementation strategy that is applied by the teachers in the class.

\section{METHOD}

\section{Research Design}

This study is qualitative research with a phenomenological approach. This study aims to explore the teachers' knowledge on the character of the spirit of nationality and teachers' teaching strategies in integrative thematic learning with social science (IPS) subject matters.

\section{Population, Samples and Sampling Techniques}

The subjects in this study were 25 elementary school teachers (13 female teachers and 12 male teachers) from 18 public elementary schools and 7 private primary schools of 8 provinces in Indonesia. The research subjects were chosen randomly, with several considerations. The consideration is that all teachers have experience in integrative thematic teaching with social science (IPS) subject matters. In addition, the research subjects were class teachers, not subject teachers. 


\section{Data Analysis}

All teachers were involved in focus group discussions (FGD) and in-depth interviews so that the researchers obtained detailed information. The FGD and interview covered 6 sub-themes consisting of 1) the teachers' knowledge about the character of the spirit of nationality, 2) the importance of the character of the spirit of nationality, 3) strategies to improve the character of the spirit of nationality of students, 4) strategies to enhance the character of the national spirit of students, 5) obstacles in applying the character of the spirit of nationality of students, 6) measurements and assessments of the character of the spirit of nationality. The data obtained from the FGD and interview were analyzed and presented in tables to be classified into sub-themes. The data analysis from the FGD and interviews employed used the Bogdan and Biklen's (1982) model to find out the relationship between subthemes.

Before the FGD and interviews were conducted, the researchers told the participants that this study would only gain teachers' knowledge information on the character of the spirit of nationality and its implementation strategies in teaching and learning. The FGD and interview were conducted naturally to obtain credible information. All teachers' names were kept confidential and only used codes to ensure the answers provided do not affect their profession as a teacher.

\section{FINDINGS}

The results of this study provide information on teachers' knowledge on of the character of the spirit of nationality. The teachers' perceptions are classified into the teachers' knowledge of the character of the spirit of nationality, strategies to improve the character of the spirit of nationality, obstacles in applying the character of the spirit of nationality, the urgency of the character of the spirit of nationality compared to other characters, and the measurements and assessments used.

\section{Teachers' Knowledge on the Character of the Spirit of Nationality}

The results of the data analysis and reduction of teachers' knowledge on the character of the spirit of nationality are in the medium category. Some teachers still find it difficult to distinguish between the spirit of nationality and patriotism. They assume that the spirit of nationality is the patriotism and vice versa. The same results can be seen in Table 1. Based on teachers' responses through the results of the interview and FGD, not all teachers understand the spirit of nationality very well. The teachers still cannot distinguish between the spirit of nationality, nationalism, and patriotism. Although the character of the spirit of nationality is a government policy to instill character education for students in schools that always appear in teacher training activities and the 2013 Curriculum socialization, teachers cannot understand the definition. 
Table 1

The teachers' knowledge on the definition of character of the spirit of nationality

\begin{tabular}{|c|c|}
\hline $\begin{array}{l}\text { Definition of Character of the Spirit of Nationality According to Elementary } \\
\text { School Teachers }\end{array}$ & $\begin{array}{l}\text { Verification } \\
\text { Results }\end{array}$ \\
\hline Reflections on the attitudes of the heroes in loving their nation and country. & \multirow{10}{*}{$\begin{array}{l}\text { Not all } \\
\text { teachers } \\
\text { understand } \\
\text { the definition } \\
\text { of the spirit } \\
\text { of nationality. } \\
\text { Some } \\
\text { teachers } \\
\text { consider that } \\
\text { the spirit of } \\
\text { nationality is } \\
\text { the patriotism }\end{array}$} \\
\hline $\begin{array}{l}\text { The people's spirit to maintain independence by carrying out their duties as a } \\
\text { good citizen }\end{array}$ & \\
\hline The spirit of citizens in upholding and defending the Country & \\
\hline The spirit of nationality is related to Bhineka Tunggal Ika & \\
\hline $\begin{array}{l}\text { A way of thinking, acting, and having insight that places the interests of the } \\
\text { nation and country above personal interests }\end{array}$ & \\
\hline The spirit of nationality is the attitude of patriotism & \\
\hline Character or behavior that reflects the love to the Indonesian nation & \\
\hline The spirit of maintaining national independence & \\
\hline Characters in accordance with Pancasila values & \\
\hline The attitude of patriotism and willing to sacrifice for & \\
\hline
\end{tabular}

Table 2 shows the results of the data analysis and reduction on the teachers' knowledge of the importance of the character of the spirit of nationality. The teachers' response to the second sub-theme proves that most of the teachers said that the character of the spirit of nationality is very important because it can improve a spirit to defend the nation and country. Therefore, learning that integrates the character of the spirit of nationality is very important.

Table 2

The teachers' knowledge on the importance of character of the spirit of nationality

\begin{tabular}{|c|c|}
\hline The Importance of Character of the Spirit of Nationality & Verification Results \\
\hline Everything done by someone is not far from national values. & \multirow{7}{*}{$\begin{array}{l}\text { All teachers realize } \\
\text { the importance of the } \\
\text { character of the spirit } \\
\text { of nationality for } \\
\text { students, which is to } \\
\text { preserve and maintain } \\
\text { the NKRI. }\end{array}$} \\
\hline $\begin{array}{l}\text { Can improve a spirit of unity and association as well as an attitude of } \\
\text { tolerance with other people. }\end{array}$ & \\
\hline $\begin{array}{l}\text { To provide exemplary of the fighting spirit of Indonesian heroes in } \\
\text { preserving and maintaining the NKRI. }\end{array}$ & \\
\hline To be an innovative generation capable of developing the country & \\
\hline To improve a sense of nationalism and patriotism & \\
\hline To foster a sense of respect and patriotism & \\
\hline To make the young generation is not easily divided & \\
\hline
\end{tabular}

Based on their responses, all teachers realize the importance of the character of the spirit of nationality, although there are some teachers who state the character of the spirit of nationality is quite important. The teachers stated that the character of the spirit of nationality as the basis for improving an attitude of belonging and loving in order to maintain the NKRI. Based on the results of the teachers' response, it can be concluded that the teachers already know the importance of the character of the spirit of nationality.

In the third sub-theme, the teachers were asked to explain the strategy of implementing the character of the spirit of nationality in the learning process. In the same sub-theme, the teachers were expected to describe learning models that are appropriate for implementing the character of the spirit of nationality. Then, the results can be seen in Table 3 . 
Table 3

The Teachers' knowledge of the application of character of the spirit of nationality in the learning process

\begin{tabular}{|c|c|}
\hline $\begin{array}{l}\text { The ways to apply the character of the spirit of nationality in the learning } \\
\text { process }\end{array}$ & $\begin{array}{l}\text { Verification } \\
\text { Results }\end{array}$ \\
\hline $\begin{array}{l}\text { Through the learning process carried out inside and outside the class. For } \\
\text { example, singing the Indonesia Raya song at the beginning of the lesson, } \\
\text { attending the flag ceremony in an orderly manner, obeying school rules, } \\
\text { etc. }\end{array}$ & \multirow{8}{*}{$\begin{array}{l}\text { The teachers } \\
\text { already know how } \\
\text { to apply the } \\
\text { character of the } \\
\text { spirit of nationality } \\
\text { in learning process, } \\
\text { which is through } \\
\text { integration of the } \\
\text { values of learning } \\
\text { spirit in the subject } \\
\text { matters, giving } \\
\text { concrete examples, } \\
\text { and through } \\
\text { habituation. }\end{array}$} \\
\hline $\begin{array}{l}\text { Give examples directly regarding the things related to the spirit of } \\
\text { nationality }\end{array}$ & \\
\hline $\begin{array}{l}\text { To internalize the interpretation of sila 1-5 within the self, then introduce } \\
\text { it to the children }\end{array}$ & \\
\hline Discipline in every activity at school & \\
\hline $\begin{array}{l}\text { Give a good example and invite together to apply the character of the } \\
\text { spirit of nationality in everyday life and provide rewards and pusnishment }\end{array}$ & \\
\hline $\begin{array}{l}\text { By introducing good and bad concrete examples as well as the } \\
\text { consequences obtained both the good and bad ones from the spirit of } \\
\text { nationality }\end{array}$ & \\
\hline $\begin{array}{l}\text { Provide understanding of how the heroes' struggles in reaching the } \\
\text { independence of the nation }\end{array}$ & \\
\hline $\begin{array}{l}\text { Through the events of Indonesia's Independence Day commemoratic } \\
\text { August } 17 \text { or national holidays }\end{array}$ & \\
\hline
\end{tabular}

The results of the analysis show that the teachers' knowledge of applying the character of the spirit of nationality is good. The teachers also said that applying the spirit of nationality to students can be done through various learning models. The results also show that the teachers already know that implementing the character of the spirit of nationality to students can be done with learning activities that contain daily habituation and are concrete. In addition, the teachers' responses also prove that their knowledge of the application of the character of the spirit of nationality can be done through learning inside and outside the class which is integrated with the subject matters, giving concrete examples, and through habituation.

The results of the teachers' knowledge of the urgency of the character of the spirit of nationality compared to other characters can be seen in Table 4. In this sub-theme, the teachers were asked to explain the urgency that is the most underlying reinforcement of the character of the spirit of nationality compared to other characters. The results show that the character of the spirit of nationality is the basic foundation for other characters in loving and defending Indonesia. 
Table 4

The urgency that is the most underlying reinforcement of the character of the spirit of nationality compared the other characters

\begin{tabular}{|c|c|}
\hline $\begin{array}{l}\text { The urgency that is the most underlying reinforcement of the character of the } \\
\text { spirit of nationality }\end{array}$ & Verification Results \\
\hline $\begin{array}{l}\text { Making students as good citizens by implementing religious values along } \\
\text { with the values of Pancasila and the spirit of defending the country. }\end{array}$ & \multirow{6}{*}{$\begin{array}{l}\text { All the teachers said } \\
\text { that the character of } \\
\text { the spirit of } \\
\text { nationality has an } \\
\text { important urgency } \\
\text { because it is used as a } \\
\text { basis for instilling } \\
\text { other characters. }\end{array}$} \\
\hline Can foster national identity as well as a sense of nationalism and patriotism. & \\
\hline $\begin{array}{l}\text { As a foundation of wholeness and advance of the nation to become a } \\
\text { peaceful, fair, and prosperous nation }\end{array}$ & \\
\hline Become the foundation of patriotism & \\
\hline $\begin{array}{l}\text { Making students not easily influenced by values from outside that are not } \\
\text { suitable with the character of the Indonesian nation, as well as the main } \\
\text { foundation of other characters. }\end{array}$ & \\
\hline $\begin{array}{l}\text { As an anticipation of the flow of globalization which is marked by the } \\
\text { advance of science and technology }\end{array}$ & \\
\hline
\end{tabular}

The instillation of the spirit of nationality in school certainly has several obstacles. These obstacles come from the self (the teachers) and the surrounding environment. According to the teachers' perceptions based on the results of the data analysis and reduction, the following in Table 5 shows some obstacles in instilling the character of the spirit of nationality.

Table 5

Obstacles in instilling the character of the spirit of nationality

\begin{tabular}{ll}
\hline Obstacles in instilling the character of the spirit of nationality & Verification Results \\
\hline Inadequate facilities and media & $\begin{array}{l}\text { In instilling the } \\
\text { character of the spirit } \\
\text { of nationality, some } \\
\text { teachers encounter } \\
\text { several obstacles } \\
\text { including a lack of } \\
\text { instilling the spirit of nationality }\end{array}$ \\
$\begin{array}{ll}\text { Less interesting way of delivering material } \\
\text { understanding of the } \\
\text { spirit of nationality by } \\
\text { knowledge not want to listen to the teachers' explanation of the } \\
\text { teachers, facilities that } \\
\text { are less supportive, } \\
\text { and a lack of support } \\
\text { nationality }\end{array}$ & $\begin{array}{l}\text { from the surrounding } \\
\text { environment }\end{array}$ \\
\hline Lack of literature about the spirit of nationality & \\
\hline Lack of habituation in children & \\
\hline $\begin{array}{l}\text { Lack of understanding of the character of the spirit of nationality of the } \\
\text { teacher }\end{array}$ & \\
\hline $\begin{array}{l}\text { The instillation of character of the spirit of nationality in low grade } \\
\text { students still needs assistance }\end{array}$ & \\
\hline Family and community environment that is less supportive &
\end{tabular}

Based on the results of the above analysis, it can be seen that the obstacles in implementing the character of spirit of nationality are not only from the teachers, but also from students. The obstacles that often arise in the field are the limited resources and learning media and the lack of creativity of the teachers in presenting material about the spirit of nationality. Thus, it resulted for students to have low motivation to learn about the spirit of nationality. Moreover, in implementing the character of the spirit of nationality, the teachers also take measurements and assessments. The results of the data analysis and reduction are summarized in Table 6. Their responses show that most teachers can measure and assess the character of the spirit of nationality through various forms of measurement and assessment. 
Table 6

The teachers' knowledge on measuring and assessing the character of the spirit of nationality

\begin{tabular}{|c|c|}
\hline $\begin{array}{l}\text { The teachers' knowledge on measuring and assessing the character } \\
\text { of the spirit of nationality }\end{array}$ & Verification Results \\
\hline Through the attitude shown every day at school & \multirow{8}{*}{$\begin{array}{l}\text { Most teachers already have } \\
\text { ideas about the appropriate } \\
\text { instruments to assess the } \\
\text { spirit of nationality, such as } \\
\text { through observation of daily } \\
\text { activities, observation, } \\
\text { attitude assessment (the } \\
\text { behavior), skills assessment } \\
\text { (practice in daily life), self- } \\
\text { assessment, and assessment } \\
\text { among friends }\end{array}$} \\
\hline $\begin{array}{l}\text { Observation of students' daily activities both inside and outside the } \\
\text { class and written/oral assessment }\end{array}$ & \\
\hline Attitude assessment by means of daily observation & \\
\hline $\begin{array}{l}\text { Through attitude assessment (the behavior) and skills (practice } \\
\text { singing national songs) }\end{array}$ & \\
\hline $\begin{array}{l}\text { Through students' behavior while attending flag ceremony } \\
\text { activities and singing national mandatory songs }\end{array}$ & \\
\hline By seeing changes in students' character & \\
\hline Using self-assessment and assessment among friends & \\
\hline $\begin{array}{l}\text { Seeing students' attitudes when attending national holiday } \\
\text { commomerations }\end{array}$ & \\
\hline
\end{tabular}

The above results clearly show that the teachers already know about instruments that can be used to measure the character of the spirit of nationality of students, such as using an observation sheet or attitude assessment. The character of the spirit of nationality is a character in which the assessment cannot be measured by cognitive assessment. In the table above, none of the teachers clarified that the character of the spirit of nationality can be measured using cognitive assessments, such as tests and the others similar to them.

\section{DISCUSSION}

The current applicable curriculum in Indonesia is the 2013 curriculum. The learning process in the 2013 curriculum is thematic-integrative learning. In the 2013 curriculum learning process, in addition to being required to have cognitive abilities, students also need to have superior character values. One of the characters that must be instilled and developed in students is the character of the spirit of nationality. The spirit of nationality is a way of thinking, acting, and having insight by placing the interests of the nation and country above both group and personal interests (Kemendikbud, 2010, p. 10). Based on this definition, the possibility of teachers to understand the character of the spirit of nationality is still lacking. Furthermore, teachers will experience a very difficult time when integrating the character of the spirit of nationality appropriately in the learning process if it is not accompanied by regular socialization and training from the government.

The findings of this study show that some teachers still misunderstand the character of the spirit of nationality. Some teachers consider that the character of the spirit of nationality is the character of patriotism (respondents 5 and respondent 18). Other teachers also view that the character of the spirit of nationality as the interpretation of the values of Pancasila (respondent 11). Based on the facts above, it is known that not all teachers understand the character of the spirit of nationality, so that socialization and training are still needed to introduce and sharpen the character of the spirit of nationality for elementary school teachers. The quality of socialization and training is very important so that teachers can gain more ability and skills to understand the integration of the character of the spirit of nationality in the learning process. Retnawati (2015) stated that the 2013 curriculum socialization and training for teachers is still lacking. Some problems are found in training and socialization, such as training and socialization have not been able to provide a good and comprehensive understanding of the 2013 Curriculum. This is due to time constraints so the delivery of material is incomplete. This issue needs to be followed up so that further training and socialization can be conducted. 
In general, the character of the spirit of nationality is inseparable or far different from the attitude of nationalism. This is because the character of the spirit of nationality is derived from the attitude of nationalism. Nationalism is used to illustrate two important phenomena (Heimonen, M \& Hebert, 2012). First, the attitude of members of a nation to care about the identity of their country. Second, actions taken by citizens to defend their fate. The character of the spirit of nationality is very important to be applied in the learning process so that students have a sense of caring for their nation in maintaining the fate of the Indonesian nation. In the learning process of the 2013 curriculum in elementary school, the character of the spirit of nationality is one of the indicators of student success. The character of the spirit of nationality is the basic foundation for improving other characters in the learning process. Therefore, both students and teachers must realize the importance of the character of the spirit of nationality for students.

The issue of the character of the spirit of nationality in the implementation of the learning process in Indonesia requires real change. The results of the study conducted by Ahmad (2014) showed that there are two teachers' perceptions of educational change, which are positive perceptions and negative perceptions. The positive perceptions foster a desire to change and innovate, while the negative perceptions show the unreadiness of the teachers to make changes. Avargil, Herscovitz, and Dori (2012) said that students also support the professional development of teachers and vice versa. This can be seen from one of the responses of the teachers who said that the character of the spirit of nationality is important "because we, especially students, are the next generation of the nation who must struggle to advance and defend the NKRI". In his response, the teacher also said "we", which means that the character of the spirit of nationality is not only needed by students but also by the teachers.

The results of the study show that most teachers have realized the importance of the character of the spirit of nationality. This teachers' awareness shows that they are ready to make changes and increase the character of the spirit of nationality during the learning process. Some of the results of previous studies (Andersson, 2019; Anis and Tijan, 2013; Fadlilatun, 2016; Setiawati, 2016) found that there were still obstacles in implementing the character of the spirit of nationality following the demands of the 2013 curriculum, but the results of this study show that teachers believed the importance of applying the character of the spirit of nationality in the learning process. The aforementioned teachers' belief will foster teacher enthusiasm in making innovations and changes that are in line with the teachers' positive perception of curriculum changes and foster teachers' desire to innovate in order to support the implementation of the 2013 curriculum.

This situation is not much different from some countries in South Asia. Countries such as India, Pakistan, and Bangladesh also have a national spirit that is not good enough (Raychaudhuri, 2015). There is still some tension due to religious differences or differences in groups or races that lead to disputes. This situation is a strong reason that the national spirit needs to possess for the emergence of unity.

To realize the importance of the character of the spirit of nationality, the teachers need to teach using various methods to students through integration in various subject matters. The method used must be innovative, which is a student-centered method (Sumarmo \& Nishitani, 2010), the use of constructivism, and providing opportunities for students to explore their abilities. Some innovative methods that can be used to implement the character of the spirit of nationality in learning include carrying out the guiding values of national heroes by fostering student morals through student discipline that is done by giving good examples and habituation in daily life (Chaerulsyah, 2014), internalization of the values of the spirit of nationality through religious (PAI) lessons (Wibowo, 2014), reinforcement the spirit of nationality through local wisdom (Rachmadyanti, 2017), and 
reinforcement the spirit of nationality through integrated learning process (Septikasari, 2002) which is in the 2013 curriculum.

Other results also show that the instillation of the character of the spirit of nationality can be done through the use of learning media which are not only interesting, but can also instill various characters including the character of nationalism. The media such as picture books that tell the story of the resistance of the Indonesian people against the West and the events of the proclamation, the use of interactive multimedia in the form of videos and quizzes, as well as textbooks based on augmented reality. Regarding the teachers' knowledge on instilling the character of the spirit of nationality to students by using various methods in the learning process, the teachers may have been trained through the application of the 2013 curriculum or conducted a separate training on the spirit of nationality. In addition, teachers can also obtain information about models of instilling the character of nationality in the learning process from the teachers' textbooks or other references. However, the teachers' knowledge of various models of instilling the character of nationality in the learning process cannot be used as a standard to measure the success of teachers in instilling the character of the spirit of nationality. The teachers also need to know about the urgency of the character of the spirit of nationality compared to other characters, the obstacles in instilling the character of the spirit of nationality through learning process, as well as activities in each way of instilling the character of the spirit of nationality in certain learning process so as to enhance the character of the spirit of nationality of students.

Although it is integrated into the learning process in the form of themes, the efforts to instill the character of the spirit of nationality in the 2013 curriculum remain focused on the basic competencies of social science (IPS). This is because in basic competencies of social science (IPS), a lot of subject matters can be used as a medium to instill the character of the spirit of nationality of students. As for the values of the spirit of nationality contained in social science (IPS) material are the values of the heroes' struggle, the event of independence, and local wisdom. The materials are presented for high grade elementary school students. Whereas for low grade students, the instillation of the character of the spirit of nationality tends to be done outside the subject matters. It is expected that the instillation of the character of the spirit of nationality is truly ingrained in students.

The results of the study show that the spirit of nationality has an important urgency compared to other characters. Based on the opinions of the teachers, it is obtained an explanation that the character of the spirit of nationality is used as a foundation to form other characters. This is because the character of nationality is a way of thinking, acting, and having insight that places the interests of the nation and country above personal and group interests. If an individual already has the character of the spirit of nationality, then the next process of forming the character can be done easily. Although there are no previous studies that are relevant to the opinion of the researchers, this will be an opportunity and a challenge for further research.

In practice, teachers experience several obstacles in instilling the character of the spirit of nationality. The obstacles experienced by the teachers can come from within the teachers themselves or from outside, such as from the side of students, parents, and the community. The fundamental obstacle experienced in instilling the character of the spirit of nationality is that there are still teachers who do not understand what the definition and importance of the character of the spirit of nationality for students. The misunderstanding of the definition is the same assumption about the character of the spirit of nationality and patriotism. Even though the two are interrelated, but they have a different understanding by definition. Another obstacle that arises is the difficulty of teachers in choosing the appropriate media to deliver material related to the character of the spirit of nationality. This causes the students being careless, easily bored, and not interested in listening, even to do as instructed by the teachers. In habituation in school, there is sometimes still a lack of self-awareness from students, so 
students do not do it wholeheartedly and even seem lazy. Therefore, further research is still needed on the appropriate strategy for instilling the character of the spirit of nationality in elementary schools.

The character of the spirit of nationality in the 2013 curriculum is included in the affective aspects, so it needs to be measured or assessed. Based on the data analysis of teachers' response on the way to measure or assess the character of the spirit of nationality of students, it can be done using various forms of assessment, including through observation of daily activities, observation, attitude assessment (the behavior), skills assessment (practice in daily life), self-assessment, and assessment among friends. However, the assessment commonly used is attitude assessment in the form of observation sheets or checklists. The results of this assessment will also be reported to parents and used as a benchmark to determine the steps to instill the character of the spirit of nationality in the future

\section{CONCLUSION AND SUGGESTIONS}

The results of this study show that not all teachers understand the character of the spirit of nationality well. The teachers still find it difficult to distinguish between the character of the spirit of nationality, nationalism, and patriotism. The teachers had realized the importance of the character of the spirit of nationality for students, but the teachers' knowledge on the importance of the character of the spirit of nationality is lacking. In addition, the teachers also do not have a good ability to instill and enhance the character of the spirit of nationality to students. Although the teachers already know that to instill the character of the spirit of nationality to students can be done by using several methods (for example, integration in the subject matters, habituation of attitude, and through the use of various media), the teachers still have obstacles in its implementation. The low knowledge of teachers about the character of the spirit of nationality also creates obstacles for the instillation of the character of the spirit of nationality which will later have an impact on students. Therefore, conducting sosialization and training to the teachers to improve the character of the spirit of nationality in the learning process of 2013 curriculum is one of the recommendations that must be applied by the Indonesian Ministry of Education. In addition, the availability of learning resources such as books, access to electronic media, or other sources still needs to be further considered by governments, schools, and education experts.

Some further research on instillation of the character of the spirit of nationality to students can be done but must be based on previous studies. The knowledge and skills of teachers need to be described more broadly and in-depth so that it can be easily identified by the other parties to improve the quality of teachers. Strategies to improve the quality of teachers, especially class teachers who hold all control of the subjects in school, are more focused on professional and pedagogical competencies. Moreover, supporting media needs to be developed, so that teachers can have access to students to improve their qualifications in managing and implementing innovative teaching and learning in their respective schools.

The authors would like to greatly thank all respondents and the parties involved in this study and the Indonesia Endowment Fund for Education (LPDP) as the party providing funding to the authors.

\section{REFERENCES}

Ahlerup, P., \& Hansson, G. (2011). Nationalism and government effectiveness. Journal of Comparative Economics, 39(3), 431-451. https://doi.org/10.1016/j.jce.2011.05.001

Ahmad, D. (2014). Understanding the 2013 curriculum of English teaching through the teachers and policymakers' perspectives. International Journal of Enhanced Research in Educational Development, 2(4), 6-15. 
Andersson, H. (2019). Nature, nationalism and neoliberalism on food packaging: The case of Sweden. Discourse, Context \& Media, (xxxx), 100329. https://doi.org/10.1016/j.dcm.2019.100329

Anis, I. M., \& Tijan, S. (2013). Pendidikan Nasionalisme Melalui Pembiasaan Di Sd Negeri Kuningan 02 Semarang Utara. Unnes Civic Education Journal, 1(2).

Avargil, S., Herscovitz, O., \& Dori, Y. J. (2012). Teaching Thinking Skills in Context-Based Learning: Teachers' Challenges and Assessment Knowledge. Journal of Science Education and Technology, 21(2), 207-225. https://doi.org/10.1007/s10956-011-9302-7

Bandura, A. (1989). Human agency in social cognitive theory. American Psychologist, 44(9), 11751184. https://doi.org/https//doi.org/10.1037/0003-066x.44.9.1175

Bialik, M., Bogan, M., Fadel, C., \& Horvathova, M. (2015). Education for the 21st century: What should students learn? Center for Curriculum Redesign, 3(4), 415-420. Retrieved from www.https://www.curriculumredesign.org./

Chaerulsyah, E. M. (2014). Persepsi Siswa Tentang Keteladanan Pahlawan Nasional Untuk Meningkatkan Semangat Kebangsaan. Indonesian Journal of History Education, 3(1), 1-5.

Daryanto \& Darmiatun. (2013). Media pembelajaran perannanya sangat penting mencapai tujuan pembelajaran. Yogyakarta: Gava Media.

Fadlilatun. (2016). Penanaman Karakter Semangat Kebangsaan Di Sd Unggulan Aisyiyah Bantul. Jurnal Pendidikan Guru Sekolah Dasar, 5(11), 1033-1040.

Heimonen, M \& Hebert, D. . (2012). Patriotism and nasionalism in music education. Burlington: ASHGATE.

Hu, B. Y., Fan, X., Yang, Y., \& Neitzel, J. (2017). Chinese preschool teachers' knowledge and practice of teacher-child interactions: The mediating role of teachers' beliefs about children. Teaching and Teacher Education, 63, 137-147. https://doi.org/10.1016/j.tate.2016.12.014

Kartodirjo, S. (1993). Pengantar Sejarah Indonesia Baru: Sejarah Pergerakan Nasional dari Kolonialisme sampai Imperialisme Jilid 2. Jakarta: PT. Gramedia Pustaka Utama.

Kaufman, S. B. (2018). selft actualizing people in the 21st century: integration with contemporary theory and research on personality. Journal of Humanistic Psychology, 1-33. https://doi.org/https://doi.org/10.1177/0022167818809178

Kemendikbud. (2010). Pendidikan karakter. Jakarta: Dirjen Dikti.

Kurniawan. (2013). Pendidikan karakter. Yogyakarta: Ar-Ruzz Media.

Mayall, J.B.L \& Preece, J. . (2011). Nationalism and international relations. London: University of London.

Mei-Ju, C., Chen-Hsin, Y., \& Pin-Chen, H. (2014). The Beauty of Character Education on Preschool Children's Parent-child Relationship. Procedia - Social and Behavioral Sciences, 143, 527-533. https://doi.org/10.1016/j.sbspro.2014.07.431

Mustadi, A. (2011). Pendidikan karakter berwawasan sosiokultural (sociocultural based character education) di sekolah dasar, daerah istimewa yogyakarta (DIY). Dinamika Pendidikan, 20, 1-15. 
Priyambodo, A. B. (2017). IMPLEMENTASI PENDIDIKAN KARAKTER SEMANGAT KEBANGSAAN DAN CINTA TANAH AIR PADA SEKOLAH BERLATAR BELAKANG ISLAM DI KOTA PASURUAN. Jurnal Sains Psikolog, 6(1), 9-15.

Qodriyah, Sri Hariyati \& Wangid, M. N. (2015). Pengembangan SSP tematik integratif untuk membangun karakter kejujuran dan kepedulian siswa SD kelas II. Jurnal Prima Edukasia, 3(2), 177189.

Rachmadyanti, P. (2017). Rachmadyanti, P. (2017). Penguatan Pendidikan Karakter Bagi Siswa Sekolah Dasar Melalui Kearifan Lokal. Jurnal Pendidikan Sekolah Dasar, 3(2), 201-214. 3(2), 201214.

Raychaudhuri, T. (2015). Nationalism, Historical Aspects of: South Asia. In International Encyclopedia of Social \& Behavioral Sciences (Second Edition, Vol. 15). https://doi.org/10.1016/B978-0-08-097086-8.62068-8

Reid, A. (2010). Imperial alcherry nationalism and political identity in southeast asia. New York: Cambridge University Press.

Retnawati, H. (2015). Hambatan guru matematika Sekolah Menengah Pertama dalam menerapkan kuri-kulum baru (Guru SMP dalam penerapan kurikulum baru). Cakrawala Pendidikan, 34(3), 390403.

Risabethe, A., \& Astuti, B. (2017). Pengembangan Media Pembelajaran Untuk Meningkatkan Motivasi Belajar Dan Karakter Semangat Kebangsaan Siswa Kelas V Sd. Jurnal Pendidikan Karakter, 7(1). https://doi.org/10.21831/jpk.v7i1.15498

Rusman. (2010). Model-model Pembelajaran: Mengembangkan Profesionalisme Guru. Jakarta: Rajawali Press.

Scott, L. A. (2017). 21st century skills early learning framework. Partnership for 21st Century Skill $(P 21)$.

Septikasari, Z. (2002). Prosiding Seminar Nasional dan Call for Papers. (23), 218-226.

Setiawati, D. A. (2016). Implementasi Pendidikan Karakter Pada Peserta Didik Di Sd. Implementasi Pendidikan Karakter Pada Peserta Didik Di Sd Negeri Sinduadi 2, 5(8).

Stanford Encyclopedia of Philosophy. (2008). No Title.

Sumarmo, U., \& Nishitani, I. (2010). High level mathematical thinking: Experiments with high school and under graduate students using various approaches and strategies. Bulletin of the Faculty of Education, Gunma University, 58(9), 9-22.

Ülger, M., Yiğittir, S., \& Ercan, O. (2014). Secondary School Teachers' Beliefs on Character Education Competency. Procedia - Social and Behavioral Sciences, 131(4310), 442-449. https://doi.org/10.1016/j.sbspro.2014.04.145

Wibowo, A. . (2014). Internalisasi Nilai-nilai Karakter Bangsa Melalui Mata Pelajaran PAI pada SMA Eks RSBI di Pekalongan. Analisa, 21(2), 291. https://doi.org/10.18784/analisa.v21i02.22

Zaslow, M., Tout, K., Halle, T., Vick Whittaker, J., \& Lavelle, B. (2014). Toward the Identification of Features of Effective Professional Development for Early Childhood Educators Literature Review 
Toward the Identification of Features of Effective Professional Development for Early Childhood Educators Literature Review. U.S. Department of Education, 268. 